\title{
Division of Competences in the Field of Foreign Relations in the Polish Constitutional System
}

\author{
Stanisław Biernat
}

\section{INTRODUCTION}

The legal issues of foreign relations fall within the area between international law and the national law of particular states. ${ }^{1}$ These problems may therefore be analyzed from both or either of these points of view. The following considerations will be conducted from the perspective of Polish law. In this legal system, foreign relations law is not treated as a separate branch but as part of constitutional law. Along the axis: exceptionalism - normalization, ${ }^{2}$ Polish law is situated on the side of the latter.

The political and socioeconomic transformations of the state began in the late 1980s and early 1990s. The foundations of liberal democracy and market economy were laid then. As early as in 1989 , the first changes to the then binding Communist constitution were introduced and developed in the following years. The current Constitution dates from $1997 .{ }^{3}$ It should be added that Poland joined the European Union in 2004. ${ }^{4}$

1 See the chapter by Helmut Philipp Aust and Thomas Kleinlein, 'Introduction', this volume.

$=$ Aust and Kleinlein, 'Introduction', at pp. 6, 14.

3 'Konstytucja Rzeczypospolitej Polskiej z dnia 2 kwietnia 1997 ' 'The Constitution of the Republic of Poland'] (1997) 78 Dziennik Ustaw [Journal of Laws] item 483 as amended.

4 Treaty between the Kingdom of Belgium, the Kingdom of Denmark, the Federal Republic of Germany, the Hellenic Republic, the Kingdom of Spain, the French Republic, Ireland, the Italian Republic, the Grand Duchy of Luxembourg, the Kingdom of the Netherlands, the Republic of Austria, the Portuguese Republic, the Republic of Finland, the Kingdom of Sweden, the United Kingdom of Great Britain and Northern Ireland (Member States of the European Union) and the Czech Republic, the Republic of Estonia, the Republic of Cyprus, the Republic of Latvia, the Republic of Lithuania, the Republic of Hungary, the Republic of Malta, the Republic of Poland, the Republic of Slovenia, the Slovak Republic, concerning the accession of the Czech Republic, the Republic of Estonia, the Republic of Cyprus, the Republic of Latvia, the Republic of Lithuania, the Republic of Hungary, the Republic of Malta, the Republic of Poland, the Republic of Slovenia and the Slovak Republic to the European Union, OJ2003, No. L 236, September 23, 2003, p. 17. 
An examination of the rules concerning foreign relations in a state that regained its sovereignty relatively recently, after the liberation from Soviet domination, deserves attention. Poland was previously unable to pursue an independent foreign policy. The following considerations will focus on how foreign relations are regulated in the provisions of the Polish Constitution and constitutional practice and analyze both executive powers and activities of the Parliament in the field of foreign relations. This matter will be presented in the broader context of the features of the state's political system which have been shaped and have been evolving since 1989 .

\section{THE POLISH CONSTITUTION, INTERNATIONAL LAW AND SEPARATION OF POWERS}

There is an important provision in the Constitution which determines the place of international law in the national legal order. ${ }^{5}$ Pursuant to article 9, '[t]he Republic of Poland shall respect international law binding upon it'. In addition, the Constitution regulates the functions, tasks and competences of state authorities in the field of foreign relations. It is worth noting that the aforementioned issues were not regulated in the Constitution during the communist times.

Foreign relations form a separate area of state activity. Their specificity lies in their being directed outside of the country and towards foreign partners. Despite these specificities, foreign relations should be treated as a part of the general policy of the state together with its internal policy or, rather, with many policies in particular areas of the state's activity. ${ }^{6}$ Consistency of all policies and rules and compliance with constitutional values is therefore required. ${ }^{7}$

The starting point for further analysis is one of the main principles of the Polish constitutional and legal system: the separation of powers. It is expressed in article 10 of the Constitution of 1997:

5 Andrzej Wasilkowski, 'Przestrzeganie prawa międzynarodowego (art. 9 Konstytucji RP)' ['Observance of international law (article 9 of the Polish Constitution)'] in Krzysztof Wójtowicz (ed.), Otwarcie Konstytucji RP na prawo międzynarodowe i procesy integracyjne [Opening of the Constitution of the Republic of Poland to international law and integration processes] (Warsaw: Wydawnictwo Sejmowe, 2006), pp. 9-30.

6 Leszek Garlicki, 'Konstytucja a "sprawy zewnętrzne" ["The Constitution and "external affairs"'] (2007) 4 Przeglad Sejmowy, pp. 195-96.

7 Ryszard Piotrowski, 'Konstytucyjne uwarunkowania polityki zagranicznej' ['Constitutional determinants of foreign policy'], in Ryszard M. Czarny and Kamil Spryszak (eds.), Państwo wobec wspótczesnych wyzwań. Zagadnienia prawa konstytucyinego [The state in the face of contemporary challenges. Issues of constitutional law] (Torun: Wydawnictwo Adam Marszałek, 2012), pp. $272-87$. 
(1) The system of government of the Republic of Poland shall be based on the separation of and balance between the legislative, executive and judicial powers.

(2) Legislative power shall be vested in the Sejm and the Senate, executive power shall be vested in the President of the Republic of Poland and the Council of Ministers, and the judicial power shall be vested in courts and tribunals.

The principle of separation of powers was restored in Poland in the early 199os. Previously, the principle of 'unity of state power' had applied for several decades. The highest authority of state power was formally the Sejm (Parliament), although in reality the state was governed by the communist party.

An analysis of the current legal arrangements in the field of foreign relations shows that the tasks and competences in this area are granted to authorities belonging to different branches although their participation is unequal. The roles that have been provided for the various state authorities in this area are, on the one hand, a manifestation and, on the other, a result of the constitutional system which has been adopted.

\section{EXECUTIVE POWERS IN THE FIELD OF FOREIGN RELATIONS}

The executive power is of the utmost importance in this area and will receive a great deal of further attention. This is not surprising; on the contrary, it is a typical situation in many states with a long tradition. ${ }^{8}$

A characteristic of the executive branch in Poland is its duality expressed in article 10(2) of the Constitution. Functions, tasks and competences are vested separately in the President and the Council of Ministers (the Government). The duality was introduced by the first constitutional amendments after the collapse of the communist system in 1989. The constituent authorities of the executive are separated from each other and each have their own legitimacy.

Article $127(1)$ and (2) provide

(1) The President of the Republic shall be elected by the Nation, in universal, equal and direct elections, conducted by secret ballot.

(2) The President of the Republic shall be elected for a 5-year term of office and may be re-elected only for one more term.

8 This trend is observed to be weakening. See Garlicki, 'Konstytucja a "sprawy zewnętrzne”, p. 196. 
The President therefore derives his democratic legitimacy directly from the will of the sovereign nation.

In turn, the Council of Ministers (the Government) benefits from the support of the parliamentary majority in the Sejm - the first chamber of the Polish Parliament. The Government's legitimacy therefore derives from the principles of representative democracy (articles 4(2), 154 and 155).

The issues of foreign relations law in Poland concern largely the distribution of tasks and competences between these two segments of the executive power. The tasks and competences of both segments in the area in question have undergone a characteristic evolution after the change of the political system in 1989 .

\section{A The Temporary 'Small Constitution' of 1992 and Separation of Powers between the President and the Council of Ministers}

In 1992, a law of constitutional rank, commonly referred to as the 'Small Constitution', was passed, which was intended to be temporary.9 The need to issue it came about when it turned out that it would take more time to pass a new, 'full' Constitution, because of the controversy surrounding its future content. $^{10}$

It is important to note that the tasks and competences in the field of foreign relations were not clearly separated in the Small Constitution between the two executive segments, that is, the President and the Council of Ministers. They were assigned to both of these authorities. ${ }^{11}$

The Small Constitution stated in article 28 that:

(1) The President of the Republic of Poland shall be the supreme representative of the Polish State in internal and international relations.

9 'The Constitutional Act of 17 October 1992 on the mutual relations between the legislative and executive institutions of the Republic of Poland and on local self-government' (1992) 84 Dziennik Ustaw [Journal of Laws] item 426. The adoption of 'Small Constitutions' for transition periods during the political changes became a Polish tradition in the twentieth century. Such statutes were passed in 1919, 1947 and 1992.

10 Ryszard Chruściak, 'Mała konstytucja z 1992 r.' ['The Small Constitution of 1992'] (2007) 5 Przeglad Sejmowy, pp. 89-110.

1 On the position of the President before the entry into effect of the Constitution, Piotr Tuleja and Krzysztof Kozłowski, 'Komentarz do art. 126 Konstytucji' ['Commentary to Article 126 of the Constitution'], in Marek Safjan and Leszek Bosek (eds.), Konstytucja RP Komentarz [Constitution of the Republic of Poland, A Commentary] (Warsaw: C. H. Beck, 2016), vol. II, p. 566; Marian Grzybowski and Anna Dobosz, 'Pozycja ustrojowa Prezydenta RP a jego kompetencje w stosunkach zewnętrznych państwa' ['The President's political position and his competences in the State's external relations'] (2018) 9 Horyzonty Polityki pp. 132-37. 
(2) The President shall ensure observance of the Constitution, safeguard the sovereignty and security of the State, the inviolability and integrity of its territory as well as upholding international treaties.

In addition, article $32(1)$ provided that 'The President shall exercise general control in the field of foreign relations.'

In turn, as regards the second segment of the executive, the Small Constitution provided in article 51(1) that ' $\mathrm{t}$ ] he Council of Ministers shall conduct the internal and the foreign policy of the Republic of Poland'. Furthermore, article $52(2)$ point 7 stated that ' $\mathrm{t}$ ] he Council of Ministers shall maintain the relations and shall conclude treaties with governments of other states and with international organisations'.

It followed from the cited provisions that the separation of tasks and competences between the President and the Government was difficult. ${ }^{12}$ It was impossible to easily separate the 'exercising of the general control in the field of foreign relations' which was the competence of the President, from 'conducting the internal affairs and the foreign policy of the Republic of Poland' which, in turn, was the responsibility of the Council of Ministers. The reasons for the imperfections of these provisions were largely due to the complex political situation. Many small parties were represented in the Parliament in the early 1990s, which made it difficult to achieve a stable majority for a clear concept of executive power. As a result, compromise solutions were adopted, which were not very consistent though. ${ }^{13}$ The state of the then constitutional provisions posed a risk of establishing two separate foreign policies, specifically when the President and the Government came from different political parties. ${ }^{14}$ The legal concepts contained in the Small Constitution could create conflicts and tensions, especially as the President sought to expand his competences at the expense of those of the Government. ${ }^{15}$ It also had to do with the strong personality of President Lech Wałesa. For example, the President caused the development of the practice of his consenting to the appointment of the Foreign Minister and the National Defence Minister by the Sejm. It happened, although according to its article 61, the Small Constitution provided for the President expressing only a legally nonbinding opinion. It should be concluded, however, that

12 Ryszard Mojak, 'Stanowisko konstytucyjne Prezydenta Rzeczypospolitej Polskiej w Małej Konstytucji' ['Constitutional position of the President of the Republic of Poland in the Small Constitution'], (1993) 2 Przeglad Sejmowy, pp. 68-110.

13 Chruściak, 'Mała konstytucja z 1992 r.', pp. 96-97.

14 Grzybowski and Dobosz, 'Pozycja ustrojowa Prezydenta RP', pp. 136-37.

15 Chruściak, 'Mała konstytucja z 1992 r.', p. 103. 
despite the aforementioned problems and controversies, the unity of Polish foreign policy was not threatened. ${ }^{16}$

\section{B The Constitution of 1997 and 'Rationally Modified Parliamentarianism'}

\section{Predominance of the Council of Ministers in Foreign Affairs}

The legal structures of the presently binding Constitution of 1997 are partly a reaction to the above mentioned provisions of the Small Constitution and doubts as to their application. ${ }^{17}$

The intention of the founders of the Constitution was to eliminate the overlap of tasks and competences between the Government and the President and avoid the danger of potential conflicts. Therefore, the Constitution made a stricter separation of the role of the two segments of executive power. This pertained not only to the area of foreign relations even though it became most conspicuous there. ${ }^{18}$

During several years of work on subsequent draft constitutions, various political models and relations between the authorities were considered, referring to both the experiences of previous years of political transformation and models taken from other states. The proposals included both the presidential system with a dominant role of the President, and the parliamentary and cabinet system with a strong government and a ceremonial role of the President. Various intermediate solutions were also proposed. ${ }^{19}$

As a result, a concept was adopted which is not the realization of any of the above models in their pure form. The constructions expressed in the Constitution are referred to as the adoption of the model of 'rationally modified parliamentarianism, ${ }^{20}$ even though it is not a commonly used

16 Garlicki, 'Konstytucja a “sprawy zewnętrzne”, p. 198.

17 Tuleja and Kozłowski, 'Komentarz do art. 126 Konstytucji’, p. 570; Dariusz Dudek, 'Komentarz do art. 146 Konstytucji' ['Commentary to article 146 of the Constitution'], in Marek Safjan and Leszek Bosek (eds.), Konstytucja RP Komentarz [Constitution of the Republic of Poland, A Commentary] (Warsaw: C. H. Beck, 2016), vol. II, pp. 729-32.

18 Maria Kruk, 'Konstytucyjny system rządów. Założenia i praktyka' ['Constitutional system of government. Assumptions and practice'], in Ewa Gdulewicz, Wojciech Orłowski and Sławomir Patyra (eds.), 25 lat transformacji ustrojowej $w$ Polsce $i$ Europie Środkowowschodniej [25 years of political transformation in Poland and Central and Eastern Europe] (Lublin: Wydawnictwo Uniwersytetu Marii Curie-Skłodowskiej, 2015), pp. 13-62 at 34-35.

19 Tuleja and Kozłowski, 'Komentarz do art. 126 Konstytucji’, pp. 568-70.

$2 \circ$ Anna Chorążewska, 'Dualizm egzekutywy i jego konsekwencje: Casus sporu o reprezentację Polski w Radzie Europejskiej' ['Dualism of the executive power and its consequences: Casus of the dispute over the representation of Poland in the European Council'], in Tadeusz Mołdawa and Jarosław Szymanek (eds.), Instytucja prezydenta. Zagadnienia teorii 
expression. It is characterized by a strong position of the Council of Ministers and of the Prime Minister, supported by the parliamentary majority. The President does not play a decisive role in this model. However, his functions and tasks are not purely representative and decorative. They are more important, although limited. ${ }^{21}$ It can only be added, as a side note, that the aforementioned expression departs from the term parlementarisme rationalisé known in the French constitutional law literature. ${ }^{22}$ A comparison of the two segments of the executive power leads to the conclusion that the Constitution gave priority to the Council of Ministers (the Government). In particular, the Council of Ministers, headed by the Prime Minister, was entrusted with conducting foreign policy. ${ }^{23}$

The limitation of the President's competences in the field of foreign relations resulted from the already mentioned intention to eliminate the phenomenon of overlapping tasks and competing powers by both segments of the executive. It should be noted that the inconsistencies that occurred before the

i praktyki na tle doświadczeń polskich oraz wybranych państw obcych [The institution of the president. Issues of theory and practice against the background of Polish and selected foreign countries' experiences] (Warsaw: Elipsa Dom Wydawniczy 2010), pp. $29-52$ at 35; Jerzy Ciapała, 'Spór kompetencyjny' ['The dispute of competence'], in Leszek Garlicki, Marta Derlatka and Marcin Wiącek (eds.), Na straży państwa prawa. Trzydzieści lat orzecznictwa Trybunału Konstytucyjnego [Guarding the rule of law. Thirty years of the Constitutional Tribunal's jurisprudence] (Warsaw: Wolters Kluwer, 2016), pp. 760-81 at 767; Dudek, 'Komentarz do art. 146 Konstytucji', p. 724.

${ }^{21}$ Ciapała, 'Spór kompetencyjny', p. 769; Tuleja and Kozłowski, 'Komentarz do art. 126 Konstytucij', pp. 563-64, 570 .

22 In France, this term means a parliamentarian system of government modified by the mechanisms introduced in the constitutional solutions after World War II to limit the political game between the Parliament and the Government to provide protection against system degenerations and government instability. See Louis Favoreu et. al., Droit constitutionnel 1oth ed. (Paris: Dalloz, 2007), p. 360.

23 Małgorzata Masternak-Kubiak and Artur Preisner, 'Realizacja konstytucyjnego podziału kompetencji organów państwa w stosunkach zewnętrznych' ['Implementation of the constitutional division of competences of state authorities in external relations'], in Krzysztof Wójtowicz (ed.), Otwarcie Konstytucji RP na prawo międzynarodowe i procesy integracyine [Opening of the Constitution of the Republic of Poland to international law and integration processes] (Warsaw: Wydawnictwo Sejmowe, 2006), pp. 109-36 at 114; Garlicki, “Konstytucja a "sprawy zewnętrzne”, p. 196; Piotrowski, 'Konstytucyjne uwarunkowania polityki zagranicznej', p. 273; Lech Mażewski, 'Prowadzenie polityki zagranicznej w Rzeczypospolitej Polskiej' ['Conducting foreign policy in the Republic of Poland'] (2009) 3 Ruch Prawniczy Ekonomiczny i Socjologiczny, pp. 9-18 at 9; Barłłomiej Opaliński, 'Funkcjonowanie władzy wykonawczej z perspektywy 15 lat obowiązywania Konstytucji Rzeczypospolitej Polskiej z 1997 r.' ['Functioning of the executive power from the perspective of 15 years of the 1997 Constitution of the Republic of Poland'], in Stanisław Biernat (ed.), Konstytucja Rzeczypospolitej Polskiej w pierwszych dekadach XXI wieku wobec wyzwań politycznych, gospodarczych, technologicznych $i$ spotecznych [The Constitution of the Republic of Poland in the first decades of the 21st century in the face of political, economic, technological and social challenges] (Warsaw: Biuro Trybunału Konstytucyjnego, 2013), pp. 217-30 at 219-20. 
entry into force of the Constitution could theoretically be removed by granting a dominant position to either the Council of Ministers (government) or the President. The decision of the authors of the Constitution to adopt the first of these solutions can be partly explained by the intention to weaken the influence of President Lech Wałęsa, who, for all that, had lost the presidential election even before the Constitution was passed.

The provisions of the Constitution illustrate the assessment presented above. ${ }^{24}$ In accordance with its article 146(1), '[t]he Council of Ministers shall conduct the internal affairs and foreign policy of the Republic of Poland'. Furthermore, the Council of Ministers 'exercise[s] general control in the field of relations with other States and international organizations' (article 146 paragraph 4 item 9) and 'conclude international agreements requiring ratification as well as accept and renounce other international agreements' (article 146 paragraph 4 item 10). The provisions set out above were supplemented by a general clause in article $146(2)$, according to which ' $\mathrm{t}]$ he Council of Ministers shall conduct the affairs of the State not reserved to other State authorities or local government'. This implies a presumption of competence for the benefit of the Council of Ministers, amongst others, in matters of foreign relations, unless another provision explicitly confers competence on another state authority. The position of the Prime Minister who is the head of the Council of Ministers is also strong. ${ }^{25}$

It follows from the abovementioned provisions that the Constitution granted to the Council of Ministers certain tasks and competences which had previously been vested in the President under the Small Constitution. This reduced the risk of conflicts which, however, could not be entirely avoided, as it would yet transpire. ${ }^{26}$

2 The Constitutional Role of the President of the Republic in Foreign Affairs

The President's role in the field of foreign relations based on the Constitution of 1997 is not unequivocal. ${ }^{27}$ Generally speaking, his role has weakened in

24 Mażewski, 'Prowadzenie polityki zagranicznej w Rzeczypospolitej Polskiej', pp. 9-11; Bartosz Szczurowski, 'Komentarz do art. 133 Konstytucji' ['Commentary to article 133 of the Constitution'], in Marek Safjan and Leszek Bosek (eds.), Konstytucja RP Komentarz [Constitution of the Republic of Poland, A Commentary] (Warsaw: C. H. Beck 2016), vol. II, pp. 632-35; Dudek, 'Komentarz do art. 146 Konstytucji', pp. 760-63; Grzybowski and Dobosz, 'Pozycja ustrojowa Prezydenta RP', pp. 138-42.

25 Chorążewska, 'Dualizm egzekutywy i jego konsekwencje', pp. 35-36.

26 Garlicki, 'Konstytucja a “sprawy zewnętrzne”, p. 197; Ciapała, 'Spór kompetencyjny', p. 768.

27 Marian Grzybowski and Piotr Mikuli, 'Realizacja konstytucyjnych kompetencji Prezydenta RP w sferze stosunków międzynarodowych' ['Implementation of the constitutional competences of the President of Poland in the sphere of international relations'], in 
comparison with the previous legal status. The earlier formula that the President exercises general control in the field of international relations was not maintained because this task was assigned in the Constitution to the Government.

In order to present the role of the President in the light of the Constitution, it is necessary to distinguish his functions and tasks from his powers (competences). This distinction extends to the whole activity of the President, including the field of foreign relations.

The President's most important functions defining his position in the constitutional setup of the state are set out in article 126(1) of the Constitution:

The President of the Republic of Poland shall be the supreme representative of the Republic of Poland and the guarantor of the continuity of State authority.

In turn, the President's main tasks are defined in article 126(2):

The President of the Republic shall ensure observance of the Constitution, safeguard the sovereignty and security of the State as well as the inviolability and integrity of its territory.

Commentators stress that article 126 of the Constitution indicates the symbolic role of the President as the authority embodying the state and the majesty of the Republic of Poland also in external relations. ${ }^{28}$ The President performs this role, on a continuous basis, in various forms at home and abroad, often in a solemn manner. The above-mentioned provisions indicate the general position of the President as a defender of the most fundamental values of the state.

However, the provisions cited above alone are not a sufficient source of the powers for the President to adopt legal acts or undertake other activities having legal effects.

Marian Grzybowski (ed.), System rzadów Rzeczypospolitej Polskiej. Założenia konstytucyjne a praktyka ustrojowa [System of government of the Republic of Poland. Constitutional assumptions and political practice] (Warsaw: Wydawnictwo Sejmowe 2006), pp. 51-64; MasternakKubiak and Preisner, 'Realizacja konstytucyjnego podziału kompetencji organów państwa w stosunkach zewnętrznych', p. 111; Garlicki, 'Konstytucja a “sprawy zewnętrzne”, pp. 196-97; Piotrowski, 'Konstytucyjne uwarunkowania polityki zagranicznej’, pp. 274-75; Mażewski, 'Prowadzenie polityki zagranicznej w Rzeczypospolitej Polskiej', pp. 11-13; Opaliński, 'Funkcjonowanie władzy wykonawczej z perspektywy', p. 222; Dudek, 'Komentarz do art. 146 Konstytucji', pp. 743-44; Grzybowski and Dobosz, 'Pozycja ustrojowa Prezydenta RP', Pp. 137-42.

28 Chorążewska, 'Dualizm egzekutywy i jego konsekwencje', pp. 37-38; Ciapała, 'Spór kompetencyjny', p. 773; Grzybowski and Dobosz, 'Pozycja ustrojowa Prezydenta RP', Pp. 137, 142-47. 
With regard to the President's powers, the Constitution has adopted the concept expressed in article $126(3)$ :

The President shall exercise his tasks within the scope of and in accordance with the principles specified in the Constitution and statutes.

This means that for the President's actions to have legal effects there must be legal basis contained in specific provisions of the Constitution apart from article 126 or in the legislative acts of Parliament. ${ }^{29}$ There is therefore no presumption that the President has the competence for the performance of its tasks, since such presumption is provided for the Council of Ministers (article 146(2)). The actions of the President which have legal effects are referred to in the Constitution as 'official acts' (article 141(1)).

An analysis of the Constitution shows that the provisions that define the President's competence to undertake actions that have legal effects in the field of foreign relations are not numerous. Such is the nature of article $133(1): 3^{30}$

The President of the Republic, as representative of the State in foreign affairs, shall:

1) ratify and renounce international agreements, and shall notify the Sejm and the Senate thereof;

2) appoint and recall the plenipotentiary representatives of the Republic of Poland to other states and to international organizations;

3) receive the Letters of Credence and recall diplomatic representatives of other states and international organizations.

These are competences traditionally held by the Head of State. It is noteworthy that ratification of some international agreements is of paramount importance, although the actual conclusion of agreements is a competence of the Council of Ministers (article 146(4) point 10). In turn, the President's power to appoint ambassadors gives him the possibility to influence the staff policy in the foreign service.

The requirement for the President to have a specific legal basis for the exercise of his powers includes acts which produce legal effects (official acts). However, there are no restrictions for the President to undertake various types of activities that do not produce legal effects, but generate political consequences, domestically and abroad. From the legal point of view, they are

29 Masternak-Kubiak and Preisner, 'Realizacja konstytucyjnego podziału kompetencji organów państwa w stosunkach zewnętrznych', p. 112; Chorążewska, 'Dualizm egzekutywy i jego konsekwencje', p. 37; Tuleja and Kozłowski, 'Komentarz do art. 126 Konstytucji', p. 575.

30 Grzybowski and Mikuli, 'Realizacja konstytucyjnych kompetencji Prezydenta RP', PP. 52-54. 
treated as nonbinding actions. ${ }^{31}$ They consist in making visits abroad, receiving representatives of other states, making speeches, declarations, etc. Sometimes the mere presence of the President in a particular place and time demonstrates the great importance Poland attaches to a given event. Such activity of the President serves the purpose of carrying out the functions and tasks contained in article $126(1)$ and (2) of the Constitution.

With regard to actions which have legal effects, that is to say, official acts, an important distinction should be made between the ways in which the President exercises his powers. ${ }^{32}$

Some competences are carried out independently and do not require the approval of other state authorities. They are referred to in the legal literature as the President's prerogatives. A closed catalogue of prerogatives is contained in article 144(3) of the Constitution. In the field of broadly defined foreign relations it is only the ordering of the promulgation of an international agreement in the Journal of Laws (Dziennik Ustaw) of the Republic of Poland that is in the nature of a prerogative (article 144(3), (7)).

In principle, however, official acts of the President require for their validity the signature of the Prime Minister (article 144(2)).

All of the aforementioned powers of the President set out in article $133(2)$ of the Constitution are exercised following this procedure. Making the issuance of the acts listed therein dependent on the countersignature of the Prime Minister additionally limits the role of the President in the field of foreign relations. It is the Prime Minister who bears political responsibility before the Sejm. ${ }^{33}$

It should be noted that the dominant role of the Council of Ministers in the exercise of the executive power compared to that of the President, not only in the area of foreign relations, leads to the identification of a significant inconsistency. ${ }^{34}$ As already mentioned, the President is elected by citizens in direct and universal vote. This model of election determines his strong democratic legitimacy, which, as a natural consequence, should give him broad powers. In the light of the Polish Constitution, however, despite the recognition of the President as the supreme representative of the Republic of

31 Chorążewska, 'Dualizm egzekutywy i jego konsekwencje', pp. 38-39; Szczurowski, 'Komentarz do art. 133 Konstytucji', pp. 631-32; Grzybowski and Dobosz, 'Pozycja ustrojowa Prezydenta RP', pp. 139, 142-44.

32 Szczurowski, 'Komentarz do art. 133 Konstytucji’, p. 631; Grzybowski and Dobosz, 'Pozycja ustrojowa Prezydenta RP', p. 143.

33 Grzybowski and Mikuli, 'Realizacja konstytucyjnych kompetencji Prezydenta RP', p. 59; Kruk, 'Konstytucyjny system rządów', p. 42.

34 Kruk, 'Konstytucyjny system rządów', pp. 35-42; Dudek, 'Komentarz do art. 146 Konstytucji', p. 743 . 
Poland, his powers to carry out actions that produce legal effects are limited. ${ }^{35}$ In such a state of affairs, Presidents have attempted to strengthen their position and reduce the discrepancies between the broad democratic mandate of the President and his political role on the one hand and the real influence in the field of internal policy and foreign relations on the other. ${ }^{36}$ This happened especially in cohabitation situations when the President and the Prime Minister came from other political formations and that caused tensions. ${ }^{37}$ The most conspicuous example of a conflict caused by the President's belief that his powers are excessively limited was the dispute over the representation of Poland in the European Council.

\section{Overlapping Competences and Duty to Cooperate}

Despite the delineations made in the Constitution, some tasks in the field of foreign relations belong to both segments of the executive power. ${ }^{8}$ The tensions this may cause between them could potentially be mitigated by the introduction of an obligation for the President to cooperate with the Government. ${ }^{39}$ It is already the preamble that characterizes the Constitution

35 Kruk, 'Konstytucyjny system rządów', p. 35.

36 Garlicki, 'Konstytucja a "sprawy zewnętrzne”, p. 198.

37 Dudek, 'Komentarz do art. 146 Konstytucji', p. 743-44; Grzybowski and Dobosz, 'Pozycja ustrojowa Prezydenta RP', p. 141.

$3^{8}$ Grzybowski and Mikuli, 'Realizacja konstytucyjnych kompetencji Prezydenta RP', pp. 61-64; Garlicki, 'Konstytucja a "sprawy zewnętrzne”, p. 197; Opaliński, 'Funkcjonowanie władzy wykonawczej z perspektywy', pp. 223, 225-26; Tuleja and Kozłowski, 'Komentarz do art. 126 Konstytucji', p. 575.

39 Masternak-Kubiak and Preisner, 'Realizacja konstytucyjnego podziału kompetencji organów państwa w stosunkach zewnętrznych', pp. 110-12.; Zbigniew Witkowski, 'Dyrektywa “współdziałania władz” jako element organizujący życie wspólnoty państwowej w świetle Konstytucji RP z 2 kwietnia 1997 r.' ['Directive of the "cooperation of authorities" as an element organizing the life of the state community in the light of the Polish Constitution of 2 April 1997'], in Jan Wawrzyniak and Marzena Laskowska (eds.), Instytucje prawa konstytucyjnego $w$ dobie integracji europejskiej [Institutions of constitutional law in the era of European integration] (Warsaw: Wydawnictwo Sejmowe 2009, pp. 139-45; Chorążewska, 'Dualizm egzekutywy i jego konsekwencje’, p. 40-41; Opaliński, ‘Funkcjonowanie władzy wykonawczej perspektywy', pp. 224-25; Maciej Pach, 'Dyrektywa współdziałania władz w Konstytucji RP Z 1997 roku jako przykład ustrojowego wishful thinking' ['Directive on the cooperation of the authorities in the Constitution of the Republic of Poland of 1997 as an example of political wishful thinking'], in Stanisław Biernat, Konstytucja Rzeczypospolitej Polskiej w pierwszych dekadach XXI wieku wobec wyzwań politycznych, gospodarczych, technologicznych $i$ społecznych [The Constitution of the Republic of Poland in the first decades of the 21st century in the face of political, economic, technological and social challenges] (Warsaw: Biuro Trybunału Konstytucyjnego, 2013), pp. 205-16; Ciapała, 'Spór kompetencyjny', pp. 775-77; Szczurowski, 'Komentarz do art. 133 Konstytucji', pp. 634-35; Grzybowski and Dobosz, 'Pozycja ustrojowa Prezydenta RP', p. 141. 
of the Republic of Poland as 'the fundamental law for the State, based on ... cooperation between the public powers'.

The obligation in question has been made concrete in the context under consideration here in article 133(3) of the Constitution: "The President of the Republic shall cooperate with the Prime Minister and the appropriate minister in respect of foreign policy.'

This provision is to be understood as an obligation of the President to cooperate with the Prime Minister and the Minister of Foreign Affairs in various forms. The obligation to cooperate is assumingly not unilateral, but lies with the Prime Minister and the Minister of Foreign Affairs, too. The provisions of the Constitution do not clarify what the cooperation is about: whether it is about mutual information, coordination of activities or whether it is required to bring about a consensus of positions. Cooperation may include agreeing on foreign policy directions as well as coordinating actions on the international arena. It should be conducted in good faith with a view to avoiding conflicts. ${ }^{40}$

\section{Constitutional Conflict over the Representation of Poland in the European Union}

The Constitution was passed seven years before Poland acceded to the European Union. Therefore the Constitution does not contain any provisions relating to the EU and Poland's membership therein. However, there are provisions in the Constitution that enabled Poland to become a member of the Union. ${ }^{41}$ Article 90 of the Constitution contains 'European clause' which served as the political and legal basis for the accession to the Union. In turn, article 91 defined the position in the legal system in force in Poland of international agreements, including EU Treaties and the law established by international organizations, that is, also EU secondary law.

In 2009, the Constitutional Tribunal ruled on the conflict concerning who is to represent Poland in the European Council. ${ }^{42}$ The President was of the opinion that it was his responsibility. The Prime Minister, on the other hand,

$4^{\circ}$ Such position was taken by, e.g., the Constitutional Tribunal in its decision of 20 May 2009 (Ref. No. Kpt 2/08).

${ }^{41}$ Stanisław Biernat, 'Offene Staatlichkeit: Polen' ['Open Statehood: Poland'], in Armin von Bogdandy, Pedro Cruz Villalón and Peter M. Huber (eds.), Handbuch Ius Publicum Europaeum (Heidelberg: C. F. Müller, 2008), pp. 243-75.

42 Maria Kruk, 'Glosa do postanowienia TK z 20 maja 2009 (sygn. akt Kpt 2/o8)' ['Annotation on the Constitutional Court decision of 20 May 2009 (Ref. No. sygn. akt Kpt 2/08)'] (2010) 1 Przeglad Sejmowy 174-88; Jerzy Jaskiernia, 'Współdziałanie Prezydenta i Rady Ministrów w sferze polityki zagranicznej' ['Cooperation between the President and the Council of 
who came from another political party, considered this to be a competence vested in the Government and did not agree to change the practice under which the Prime Minister sat on the European Council. The President was even denied access to a government plane to travel to Brussels. However, the President took part in the European Council meeting together with the Prime Minister. Thereafter, the Prime Minister applied to the Constitutional Tribunal to resolve the dispute over the competence to represent Poland in the Council. The Tribunal issued its first ever decision of this kind, based on article 189 of the Constitution. ${ }^{43}$

In this ruling, the Tribunal settled the competence dispute by considering it in the wider context of the role of the state authorities in dealing with the EU institutions. It was important to establish whether the division of tasks and competences between state authorities in EU matters was the same as in the field of foreign relations. As the Constitution does not contain provisions on the separation of tasks and competences of both segments of the executive in relations with the EU, the Constitutional Tribunal decided to settle the competence dispute submitted to it on the basis of general constitutional provisions. The starting point was the conviction that relations with the European Union do not fall within the scope of either internal policy or external relations, but show, at the same time, the characteristics of both areas.

An analysis of the Constitution led the Constitutional Tribunal to the conclusion that it is the Council of Ministers (the Government) that is generally competent in European affairs due to its position as an authority with general power in the field of both home affairs and foreign relations. The Prime Minister, who heads the Government, is authorized to represent Poland in the European Council and to express Poland's position in this forum.

However, there can be no question of the Government's exclusivity in European matters. The constitutional position of the President as the supreme representative of the Republic of Poland and his tasks specified in article 126(2) of the Constitution, is not without relevance either. The Constitutional Tribunal stated that in (rather exceptional) cases, when issues falling within the scope of the President's tasks would be discussed by the European Council, he may decide to represent Poland in this EU institution. In such

Ministers in the sphere of foreign policy'] (2010) 6 Państwo i Prawo, pp. 3-18; Mażewski, 'Prowadzenie polityki zagranicznej w Rzeczypospolitej Polskiej', pp. 14-15; Ciapała, 'Spór kompetencyjny', pp. 76o-81; Tuleja and Kozłowski, 'Komentarz do art. 126 Konstytucji', p. 571; Dudek, 'Komentarz do art. 146 Konstytucji', p. 744.

43 Judgment of May 20, 2009 Ref. No. Kpt 2/08, http://trybunal.gov.pl/fileadmin/content/omo wienia/Kpt_o2_08_EN.pdf, accessed June 26, 2020. 
situations, however, the President would be obliged to present the position determined by the Council of Ministers.

The Tribunal stressed that the state cannot pursue two foreign or European policies and the division of competences while ensuring the consistency of operation by all state authorities is essential. ${ }^{44}$ An important place in the judgment under discussion is occupied by considerations concerning the obligation of the President to cooperate with the Prime Minister and the Minister of Foreign Affairs resulting from the already mentioned provisions of the preamble and article 133(3) of the Constitution.

The final conclusions of the Constitutional Tribunal's ruling may be summarized as follows: in the first place the Tribunal put forward the principle of cooperation between the public powers, expressed in the Preamble and article133(3) of the Constitution of the Republic of Poland. The obligation to cooperate rests with the President of the Republic of Poland, the Council of Ministers and the Prime Minister (who presides over the Council of Ministers), while exercising their constitutional duties and powers. As a rule it is the Council of Ministers which determines the stance of the Republic of Poland to be presented at a given session of the European Council. The Prime Minister presents the agreed stance there (article 146(1), article 146(2) and article146(4), (9) of the Constitution). The President, as the supreme representative of the Republic, may, however, decide to participate in a particular session of the European Council, if he finds it useful for the exercise of his duties, specified in article 126(2) of the Constitution. The participation of the President in a given session of the European Council requires his cooperation with the Prime Minister and the competent minister in order to ensure uniformity of actions taken on behalf of the Republic of Poland in the relations with the European Union. Such a cooperation enables the President to refer to the stance of the Republic of Poland determined by the Council of Ministers. It also makes possible to specify the extent and manner of the intended participation of the President in a session of the European Council.

\section{The Role of the President of the Republic in Practice}

1 The President As the Supreme Representative of the Republic of Poland

The constitutional arrangements outlined above according to which the President has a strictly defined and limited power to take actions with legal effect do not mean that successive Presidents are passive in the field of foreign

44 This attests to the adoption of the concept of 'normalization' in foreign relations law. See Aust and Kleinlein, 'Introduction', p. 14. 
relations. Indeed, Presidents are very active in this area. ${ }^{45}$ This can be illustrated by the endeavors of Polish President Andrzej Duda in several months of 2019. During this time, the President made many foreign visits and met with his counterparts from other states. Sometimes the anniversaries of various important events were an opportunity to make such visits. ${ }^{46} \mathrm{~A}$ separate category were multilateral conferences with Heads of State on a variety of political or social issues. ${ }^{47}$ The President's participation was aimed at emphasizing the significance and rank of these meetings and conferences for Polish interests.

The results of these visits were various documents signed by the Polish President and his partners from other countries. However, these were not international agreements and were not legally binding. They expressed the political will of the Republic of Poland and other participating countries.

\section{The President As Commander-in-Chief of the Armed Forces of the Republic of Poland}

Separate mention should be made of events in external relations with the participation of the Polish President where he acted not only as the supreme representative of the Republic of Poland (article 126(1)) guarding the sovereignty and security of the state (article 126(2)), but also as the Commander-inChief of the Armed Forces of the Republic of Poland (article 134(1)). An example of such activity is the participation of the Polish President in the meeting of the North Atlantic Council in London (3-4 December 2019) on the 7oth anniversary of NATO and the signing of the London Declaration issued by the Heads of State and Government. ${ }^{48}$ The Declaration reaffirmed, inter alia, the commitment to article 5 of the Washington Treaty. It should be noted in this context that the practice developed in the past of Poland being represented at NATO summit meetings by the President. The President is always accompanied by the Minister of National Defence, which reflects the requirements for cooperation provided for in the Constitution (article 133(3)).

45 In early 2021, it was even announced the plan to create an Office of International Policy in the Chancellery of the President.

$4^{6}$ www.president.pl/en/news/art,1079, joint-statement-by-the-presidents-of-the-republic-of-lithu ania-and-the-republic-of-poland-on-the-occasion-of-the-45oth-anniversary-of-the-union-of-lub lin.html, accessed June 26, 2020; www.president.pl/en/news/art,1144,president-commemor ates-battle-of-the-bulge.html, accessed June 26, 2020.

47 www.president.pl/en/news/art,1115,v4-meeting-starts-in-lany-czech-republic.html; www.presi dent.pl/en/news/art,1119,president-warns-against-cohesion-cap-funding-cuts.html, accessed June 26,2020 .

$4^{8}$ www.president.pl/en/news/art,1139, london-declaration-.html?fbclid=IwARzqSZMqeJHWiSb bYqDWvhUNK831lD4wD-ekvCXVBH6rsCw9LVhzSn49ZFc, accessed June 26, 2020. 
Poland's foreign policy is largely aimed at strengthening state security considering the sense of threat from Russia. The United States is considered to be the main guarantor of state security within NATO as well as beyond the framework of this Alliance. In the area of political and military cooperation with the United States, successive Polish Presidents have been very active. The result of many years' efforts is the presence of 4,500 American soldiers on the Polish territory. The President's activity was also maintained in 2019. It was manifested by two joint declarations of the Presidents of both countries. These were the Joint Declaration on Defense Cooperation Regarding US Force Posture in Poland (June 2019) and the Joint Declaration on Advancing Defense Cooperation (September 2019).

In the first of these declarations of June 12, 2019, ${ }^{49}$ the United States announced an increase in its military presence in Poland in the near future by about 1,000 additional soldiers. This will was sustained in the second declaration. Poland, on the other hand, promised to provide and maintain the jointly agreed infrastructure for an initial package of additional projects at no cost to the United States. Poland is also planning to provide additional support to the US Armed Forces, going beyond the NATO standard of support by the host country. The declaration then listed the intended specific undertakings for increasing defense cooperation in Poland. The second declaration of September 23, 2019 is an extension and detail of the first one. ${ }^{\circ}$ It lists the locations of particular US military units in Poland.

These declarations are important political documents for Poland, but do not have direct legal effects. This is evidenced by the emphasis in both declarations on the common will to strive for the conclusion of international agreements and arrangements necessary for the implementation of increased cooperation in the field of infrastructure and defense, including improvement of the functioning of the US armed forces in Poland. It follows therefrom that the declarations under discussion have a preparatory value in relation to future international agreements.

The above review shows that the President's role in the field of foreign relations is not limited to his formal competence to undertake actions with legal effects. The political implications are no less important. It should be added that the current President of Poland is considered by many observers as

49 www.president.pl/en/news/art,1069,joint-declaration-on-defense-cooperation-regarding-us-for ce-posture-in-the-republic-of-poland.html, accessed June 26, 2020.

50 www.president.pl/en/news/art,1107,joint-declaration-on-advancing-defense-cooperation.html, accessed June 26, 2020. 
a politician who is not independent, but subject to the influence of the ruling Law and Justice (PiS) party and its powerful Chairman Jarosław Kaczyński.

\section{ACTIVITIES OF THE PARLIAMENT IN THE FIELD OF FOREIGN RELATIONS}

The dominance of the executive in the field of foreign relations is undeniable. However, this does not mean exclusivity in this area. Relevant is also the activity of the Parliament ${ }^{51}$ which in Poland consists of two chambers: the Sejm and the Senate. The role of the Parliament in the field of foreign relations deserves attention because of its democratic legitimacy stemming from direct elections.

\section{Declaration of a State of War and Conclusion of Peace and Ratification of Treaties}

The Sejm - the Parliament's first chamber - has, in the light of the Constitution, a two-fold competence to take decisions in the field of foreign relations. First, under article 116(1), "the Sejm shall declare, in the name of the Republic of Poland, a state of war and the conclusion of peace'..$^{2}$ The Constitution details it in article 116(2):

The Sejm may adopt a resolution on a state of war only in the event of armed aggression against the territory of the Republic of Poland or when an obligation of common defence against aggression arises by virtue of international agreements. If the Sejm cannot assemble for a sitting, the President of the Republic may declare a state of war.

Second, the Parliament gives its consent in the form of a statute to the ratification of major international agreements. ${ }^{53}$ In accordance with article $89(1)$

ratification of an international agreement by the Republic of Poland as well as renunciation thereof, shall require prior consent granted by statute - if such agreement concerns:

${ }^{51}$ Masternak-Kubiak and Preisner, 'Realizacja konstytucyjnego podziału kompetencji organów państwa w stosunkach zewnętrznych', pp. 118-21; Garlicki, 'Konstytucja a "sprawy zewnętrzne”, pp. 198-201; Mażewski, 'Prowadzenie polityki zagranicznej w Rzeczypospolitej Polskiej', p. 13.

52 Masternak-Kubiak and Preisner, 'Realizacja konstytucyjnego podziału kompetencji organów państwa w stosunkach zewnętrznych', pp. 118-20.

53 Grzybowski and Mikuli, 'Realizacja konstytucyjnych kompetencji Prezydenta RP', pp. 54-61. 
1) peace, alliances, political or military treaties;

2) freedoms, rights or obligations of citizens, as specified in the Constitution;

3) the Republic of Poland's membership in an international organization;

4) considerable financial responsibilities imposed on the State;

5) matters regulated by statute or those in respect of which the Constitution requires the form of a statute.

In addition, specific, more demanding rules for ratification with the participation of both chambers of the Parliament refer to the international agreement based on article 9o(1) of the Constitution. Pursuant to this provision, "[t]he Republic of Poland may, by virtue of international agreements, delegate to an international organization or international institution the competence of State authorities in relation to certain matters'. This provision concerned the Accession Treaty of Poland joining the EU.

A statute, granting consent to the ratification of such an agreement shall be passed by the Sejm by a two-thirds majority vote in the presence of at least half of the statutory number of its Members, and by the Senate by a two-thirds majority vote in the presence of at least half of the statutory number of Senators. The consent to the ratification may also be granted in a nationwide referendum (article 9o(2) and (3)).

\section{Control over the Activities of the Council of Ministers in the Field of Foreign Relations and the Parliamentary Foreign Affairs Committee}

From the parliamentary perspective, noteworthy is the competence to exercise control over the Government. In accordance with article 95(2) of the Constitution, the Sejm shall exercise control over the activities of the Council of Ministers within the scope specified by the provisions of the Constitution and statutes. Clearly, the scope of parliamentary control is broader than the field of foreign relations. The activities of the Parliamentary Foreign Affairs Committee are of great practical importance. The Committee discusses current issues of the Government's foreign policy. In addition, the Committee initiates legislative work, expresses its opinion on the correctness of procedures for the ratification of international agreements and provides its opinions on candidates for positions related to the state's foreign policy. ${ }^{54}$

54 Jerzy Jaskiernia, 'Charakter prawny i funkcje Komisji Spraw Zagranicznych Sejmu RP' ['Legal nature and functions of the Foreign Affairs Committee of the Polish Sejm'] (2004) 6 Polski Przeglad Dyplomatyczny 25-130; Masternak-Kubiak and Preisner, 'Realizacja konstytucyjnego podziału kompetencji organów państwa w stosunkach zewnętrznych', p. 121; Garlicki, “Konstytucja a "sprawy zewnętrzne”, p. 200. 
Periodically, the Sejm holds debates on the foreign policy which is presented by the Minister of Foreign Affairs. This provides an opportunity for the parliamentary opposition to take a stand. It should be stressed, however, that the President's activity in the field of foreign relations remains beyond the Parliament's control. ${ }^{55}$

It can be concluded that, apart from the Parliament's competence in the process of ratification of international agreements, the Parliament's role in the field of foreign relations lies in providing opinions and inspiring the activities of the Council of Ministers. Control over the Government is general in its nature. The Parliament's real influence on the executive in this area depends largely on the qualifications and determination of Members of the Sejm dealing with international affairs in a given term of office.

\section{Parliamentary Activity in EU Affairs}

Poland's membership in the European Union has opened new fields of parliamentary activity. As already mentioned, EU affairs do not fall within the division of state activities into internal and external affairs and contain elements of both. The role of the Parliament in the European affairs is defined by EU and Polish law. The Lisbon Treaty has significantly strengthened the position of national parliaments. The various forms of participation of national parliaments in the Union's political life and the related competences are formulated in the extensive article $12 \mathrm{TEU}$ which should be mentioned in the first place. ${ }^{56}$ In this context, reference should also be made to two protocols which have the legal power of treaties. They regulate the procedures for $\mathrm{EU}$ institutions to observe the principle of subsidiarity and assessment, in this respect, of draft EU legislation by the parliaments of the Member States. ${ }^{57}$ The Polish Parliament is also involved in these procedures.

As far as Polish law is concerned, reference should be made to the Act of 2010 on the Cooperation of the Council of Ministers with the Sejm and Senate on Matters Related to the Membership of the Republic of Poland in the European Union..$^{8}$ Pursuant to the provisions of this Act, the Council of

55 Grzybowski and Dobosz, 'Pozycja ustrojowa Prezydenta RP', p. 145.

56 Tobias Lock, 'Articles 10-12', in Manuel Kellerbauer, Marcus Klamert and Jonathan Tomkin (eds.). The EU Treaties and the Charter of Fundamental Rights. A Commentary (Oxford: Oxford University Press, 2019), pp. 108-23 at $118 \mathrm{ff}$.

57 Protocol (No 1) on the Role of National Parliaments in the European Union (OJ 2016 No. C202, 7 June 2016, pp. 203-05 and Protocol (No 2) on the Application of the Principles of Subsidiarity and Proportionality (OJ 2016 No. C202, 7 June 2016, pp. 206-o9).

$5^{8}$ 'Ustawa z dnia 8 października 2010 r. o współpracy Rady Ministrów z Sejmem i Senatem w sprawach związanych z członkostwem Rzeczypospolitej Polskiej w Unii Europejskiej' 
Ministers is obliged to cooperate with both chambers of the Parliament in a number of areas: making European Union law, bringing actions before the Court of Justice of the European Union by the Sejm and the Senate, creating Polish legislation implementing European Union law, giving opinions on candidates for certain posts in the European Union as well as in connection with representatives of the Council of Ministers holding the presidency of the Council. The cooperation according to the statute in question consists mainly in the provision by the Government of information, to a broad extent, to parliamentary committees competent for European affairs, consultations and opinions on the Government's intended activities. The statute in question introduces procedures to ensure efficient cooperation.

\section{CONCLUSION}

The above considerations have illustrated the existence of various factors determining the performance of tasks and competences in the field of foreign relations in a country which just over thirty years ago gained the possibility to act independently on the international and European arena. The arrangement of political forces reflected in the parliamentary composition during the drafting and adoption of the Constitution determined the choice of the structure of the state system, including the dualism of the executive power and, within it, the relationship between the Council of Ministers (the Government) and the President. In addition to the constitutional solutions, of great relevance are the changing external conditions as well as the personality traits of politicians performing the functions of president, prime minister, ministers or members of parliament. Thanks to these characteristics, even in the unchanged constitutional state, there may be differences in the real significance of particular authorities in such an important and sensitive area as foreign relations.

Worth noting at this point are the processes of transformation of the Polish state system towards authoritarianism noticeable after $2015 .{ }^{59}$ These processes are taking place without any amendment to the Constitution, although with an interpretation of its provisions departing from what was commonly approved previously. Essentially, undemocratic changes are being made through new statutes and changes in the application of the old ones. Most

(2010) 213 Dziennik Ustaw [Journal of Laws] item 1395. Dudek, 'Komentarz do art. 146 Konstytucji', pp. 747-48.

59 Wojciech Sadurski, Poland's Constitutional Breakdown (Oxford: Oxford University Press, 2019). 
observers assert that certain of these statutes are unconstitutional. This unconstitutionality, however, cannot be effectively examined considering the loss by the Constitutional Tribunal of its prestige and public trust. The independence of courts, including the Supreme Court, has been significantly weakened.

The aforementioned political transformations have an effect on Poland's foreign relations. They result in impairing the state's reputation in the international arena due to the undermining of the principles of democracy and the rule of law. The European Union responded to these developments. ${ }^{60}$ Proceedings under article 7 TEU have been pending before the Council of the European Union since 2018..$^{61}$ These were initiated by the European Commission which believes that there is a clear risk of a serious breach by this Member State of the values referred to in article 2 TEU, and in particular the rule of law. The ECJ has issued several judgments ruling on the violation by Poland of the rule of law with regard to the judiciary. ${ }^{62}$ Poland's position in the European Union has weakened. Even if there is no formal Polexit, its increasing marginalization is to be expected.

The developments in Poland are also condemned by numerous international organizations. Poland is getting more and more isolated on the international arena.

The changes in the practice of Poland's foreign relations in recent years are invisible in an analysis limited to constitutional considerations only. In the exercise of their constitutional tasks and competences, including in the field of foreign policy, both the President and the Government headed by the Prime Minister as well as the parliamentary majority, are subject to the will of the Chair of the ruling party (PiS).

6o Armin von Bogdandy, Piotr Bogdanowicz, Iris Canor, Christoph Grabenwarter, Maciej Taborowski, Matthias Schmidt, Defending Checks and Balances in EU Member States,Taking Stock of Europe's Actions, (Berlin, Heidelberg: Springer, 2021), https://ink .springer.com/book/10.1007\%2F 978-3-662-62317-6.

${ }_{61}$ Armin Hatje and Lubos Tichý (eds.), Liability of Member States for the Violation of Fundamental Values of the European Union, Europarecht Beiheft 1 (Baden-Baden: Nomos, 2018).

62 Judgments of the Court of Justice: Case C-619/18, European Commission v. Republic of Poland [2019], ECLI:EU:C:2019:531; Case C-192/18, European Commission v. Republic of Poland [2019], ECLI:EU:C:2019:924; Joined Cases C-585/18, C-624/18 and C-625/18, A. K. and Others v. Sąd Najwyższy [2019], ECLI:EU:C:2019:982. 